鉄道駅周辺地域における地域施設の分布実態と

$$
\text { その経年変化について }
$$

\title{
ON THE TEMPORAL CHANGE OF DISTRIBUTION PATTERNS \\ OF COMMUNITY FACILITIES AROUND RAILWAY STATIONS
}

\author{
李 明 權*, 柏原士 郎**, 吉村英祐***, 横田 隆司**** \\ Myungkwon LEE, Shiro KASHIHARA, Hidemasa YOSHIMURA and Takashi YOKOTA
}

\begin{abstract}
This study aims to clarify the temporal change of spatial distributions of community facilities around railway stations for their appropriate location planning. We surveyed fourteen different areas around railway stations in naturally developed built-up areas mainly using residential maps. As a result, we point out the characteristics of distribution patterns of various facilities by the passage of time. They are classified into four types. We also found that railway stations have a great influence on generation of community facilities around them.
\end{abstract}

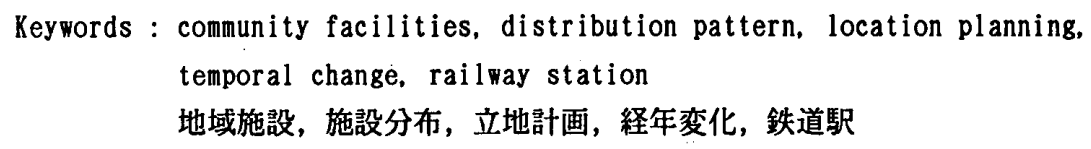

\section{1，目的と意義}

鉄道駅やショッピングセンター等の集客効果の大きい 都市施設の立地が周辺地域に与えるインパクトは大きく， その影響を的確に予測し，その予測結果を織り込んだ都 市空間の構成手法を提示することは, 魅力的で利便性に 富んだ街づくりをおこなうための重要な課題のひとつで あると考えられる。そこで, 本報告では, まず鉄道駅を 取り上げ，その周辺地域に発生する地域施設の分布実態 を時系列的に明らかにすることを目的として分析を試み た。

すなわち，本報告は，鉄道駅やショッピングセンタ 一等の都市施設の都市空間における開発の核としての効 果を最大限に活用し，施設の自然発生を計画的に誘導・ コントロールし, 魅力的な都市空間を構成するための方 法を示すことを目的とした研究の一部として位置づけら れる基礎的研究であり，施設発生の予测モデルを作成す るための基礎となるすのである。

\section{2. 研究の方法}

(1) 調查の対象地域と対象施設

鉄道駅周辺地域における地域施設の分布状況は，駅の 乗降客数の規模によっても異なると考えられる。そこで， 大阪府下の鉄道駅の中から 1 日の平均乗客数 20.000 30.000 人程度の駅として阪急宝塚線の豊中駅と京阪電鉄 本線の大和田駅，10,000 20,000人程度の駅として阪急 宝塚線の兽根駅と京阪電鉄本線の門真市駅および阪急箕 面線の箕面駅，10.000人以下の駅として近鉄東大阪線の 新石切駅と南海高野線の住吉東駅の計 7 つの駅を調查対 象駅に選定した。各駅の乗客数と周辺地域の人口は表一 1 のとおりである。

調查は約 80 業種を対象にして実施したが, 紙面の都 合で，主として地域住民の利用に供されると考えられる 16 業種 (図一 6 参照) を選定し報告する。

(2) 研究方法

研究の手順および分析方法は次のとおりである。

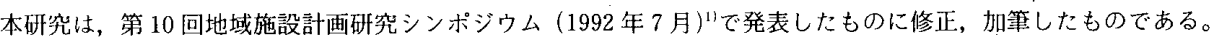

* 大阪大学大学院工学研究科 大学院生・工修 Graduate Student, Dept. of Architectural Eng., Osaka Univ.,

** 大阪大学工学部建築工学科 教授 $\cdot$ 工博

*** 大阪大学工学部建築工学科 助教授 $\cdot$ 工博 M. Eng.

Prof., Dept. of Architectural Eng., Osaka Univ., Dr. Eng.

Assoc. Prof., Dept. of Architectural Eng., Osaka Univ., Dr. Eng.

**** 大阪大学工学部建築工学科 助手 $\cdot$ 工博

Research Assoc., Dept. of Architectural Eng., Osaka Univ., Dr. Eng.
} 
表- 1 各駅の乗客数と周辺地域の人口

\begin{tabular}{c|c|c|c}
\hline 駅 名 & 年度 & 人口 (人) & 乗客数 (人) \\
\hline 阪急宝塚線 & 1969 & 16,449 & 33,423 \\
豊中駅 & 1990 & 13,880 & 30,883 \\
\hline 京阪電鉄本線 & 1984 & 26,072 & 19,934 \\
大和田駅 & 1990 & 26,536 & 21,695 \\
\hline 京阪電鉄本線 & 1984 & 19,325 & 11,634 \\
門真市駅 & 1990 & 18,963 & 15,757 \\
\hline 阪急宝塚線 & 1969 & 23,529 & 16,769 \\
曽根駅 & 1990 & 21,870 & 16,115 \\
\hline 阪急箕面線 & 1972 & 11,126 & 10,842 \\
箕面駅 & 1990 & 11,001 & 11,912 \\
\hline 近鉄東大阪線 & 1977 & 9,614 & -- 拄 1) \\
新石切駅 & 1990 & 9,566 & 7,665 \\
\hline 南海高野線 & 1984 & 22,545 & 5,079 \\
住吉東駅 & 1990 & 21,081 & 4,807 \\
\hline \multicolumn{4}{|c}{ (乗客数は 1 日当たりの平均値) } \\
\multicolumn{4}{|c|}{ (各年度別大阪府統計年鑑による) }
\end{tabular}

(1)まず鉄道駅周辺地域の範囲を設定する。駅周辺地域の 範囲は駅勢圈, 幹線道路や河川の位置, 人口分布状況 などを考慮して, 駅の主要改札口を中心にして半径約 $800 \mathrm{~m}$ 範囲に設定した。

(2)鉄道駅周辺地域における地域施設の分布実態を明らか にするため，駅周辺地域における過去（本報では1990 年以前の調查時点を過去と呼ぶ)注 2 ) と現在 (1990年 の調查時点を現在と呼ぶ）の住宅地図注3)を用いて, 各種の地域施設の分布実態を調查し、現地調查を併用 して地図上にブロットし，分布図を作成する。

(3)駅の影罯を量的にとらえるために, 駅からの距離と施 設数，施設原単位との関係を分析する。

\section{（3）用語の定義}

a . 地域施設 : 地域施設とは一般に教育施設, 医療施設, 公共・行政施設, 商業施設, サービス施設など地域住 民の利用に供される施設を指すが，本報告では図－6 に示す諸施設を分析対象とする。なお，本報告では， 地域施設を単に施設と呼ぶことがある。

b. 施設原単位 : 単位人口当たりの施設数（施設数 $/ 1$ 万人）。なお，人口は各調查時点の常住人口とする。 各分析対象地域の人口は, 各調查時点の町丁別人口を るとにして算出した。さらに, 駅からの距離と施設原単 位の関係を求めるために，図ー 1 に示すように半径 200 m刻みの同心円により地域を分割し，各ドーナッ状のソ ーン内の施設数を同ゾーンの人口で除して, 各ゾーンご との施設原単位を求めた。なお, ゾーン内の人口は各町 丁人口が均一に分布すると仮定し，ゾーン内に含まれる 面積の割合で配分して求めた。また, 同心円の中心は各 駅の主要改札口の位置とした。

\section{3、調查対象地域およひ施設分布の概要}

各調查対象地域における〈現在〉（1990年）の用途地
域を図ー 2 に示す。

全調查地域における各施設ごとの分布実態の一部を図 - 3 に示す。各対象地域における調查全業種の分布実態 は, 駅の北側が山地である箕面を除くと〈過去〉と〈現 在）のいずれにおいてす各調查地域の全範囲にわたって 施設が広く分布していること, 全業種とす〈現在〉の方 が〈過去〉に比べ施設数が多くなる傾向が読みとれる。

以下に各地域ごとの施設分布の概要をみる。

a . 箕面地域：商業地域は駅の北側に設定されているが, 駅の北側が山地になっているため，施設は少なく，駅の 南側の近隣商業地域に施設が多く分布している。また, バス便が通っている道沿いに施設が分布している傾向も

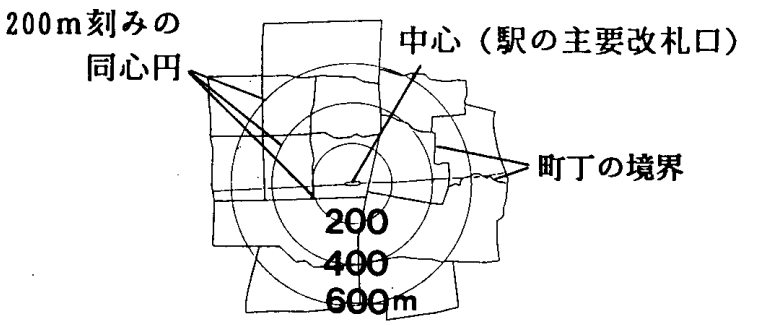

図ー1 距離圈の説明図
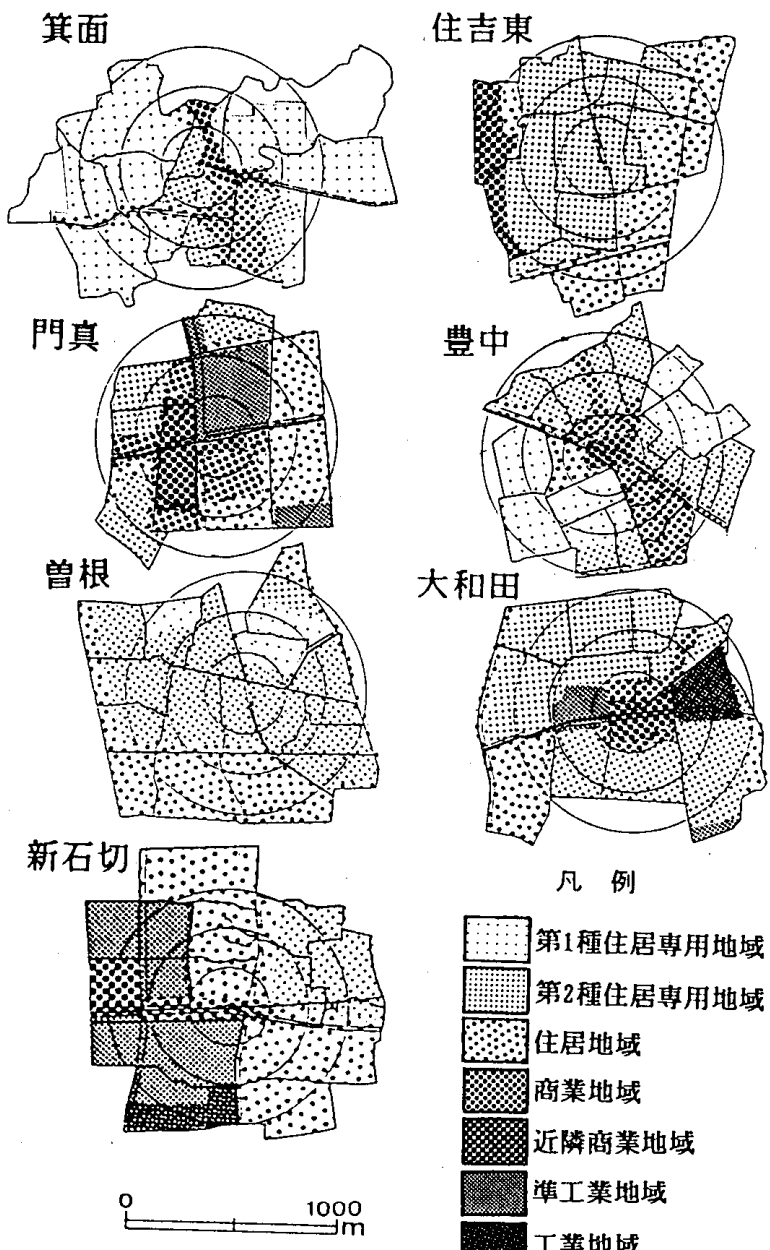

凡 例

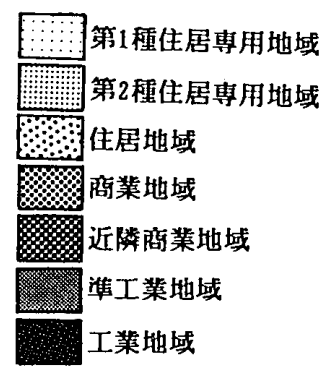

図ー2 各調查地域における用途地域の分布 
16業種全体

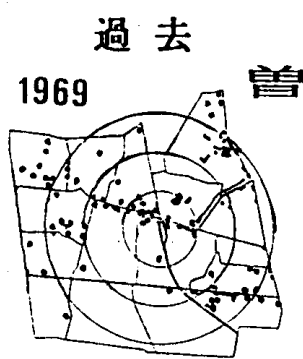

1984

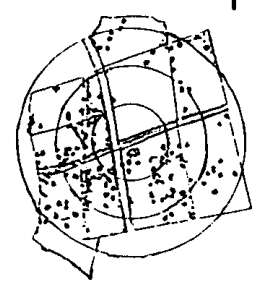

阳真 1990

1977 新石切 1990
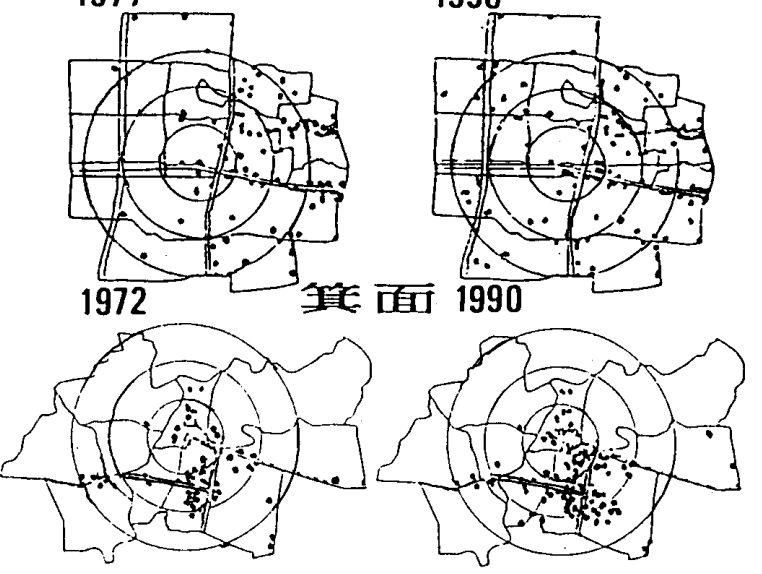

1984 住吉東 1990
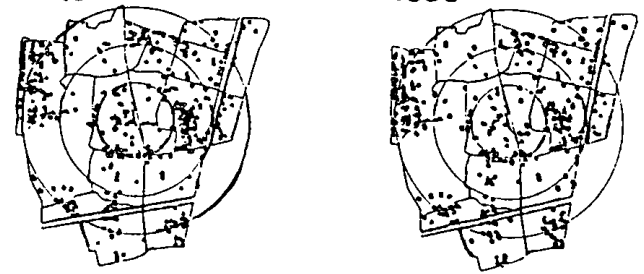

1984 大和时1990
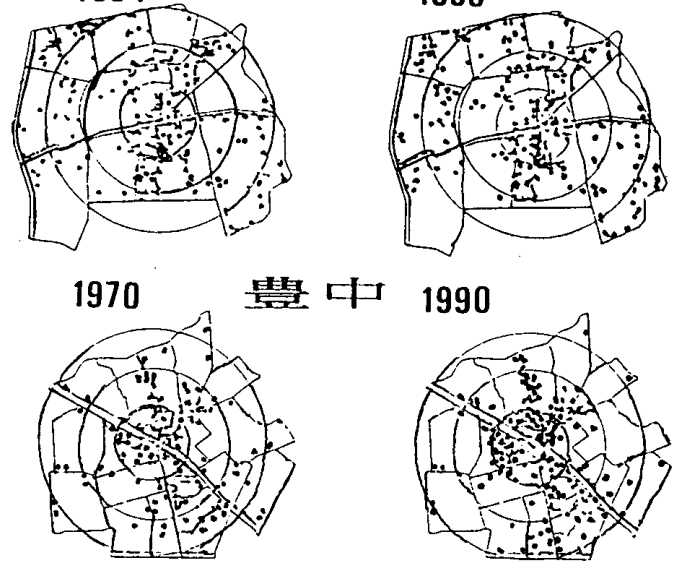

涟中 1990

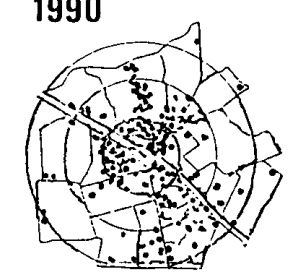

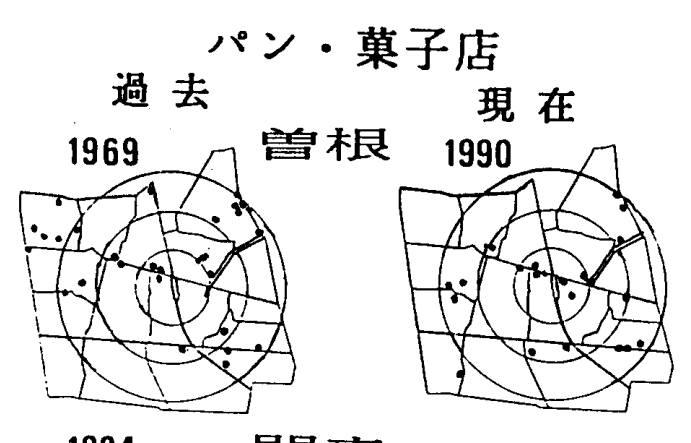

1984

成真 1990
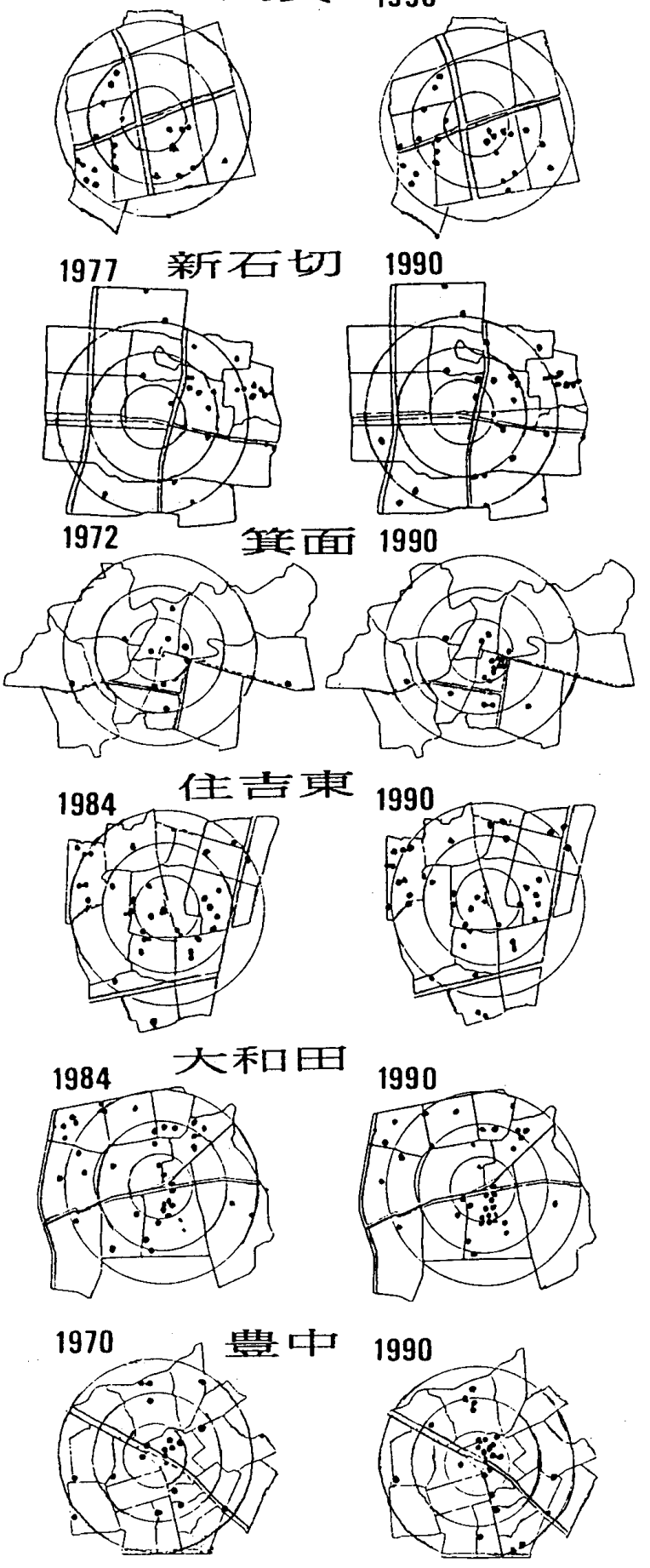

O 1000

图一３各調查地域における各施設の分布実態（１６業喠とパン・菓子店） 
食堂・飲食店

過去

1969 兽根 1990
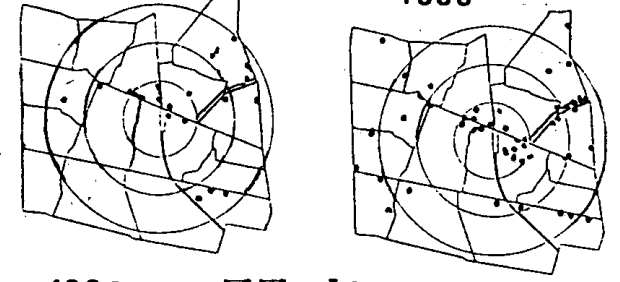

1984 門真 1990

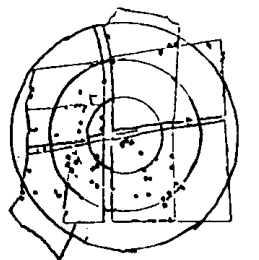

1977 新石切 1990

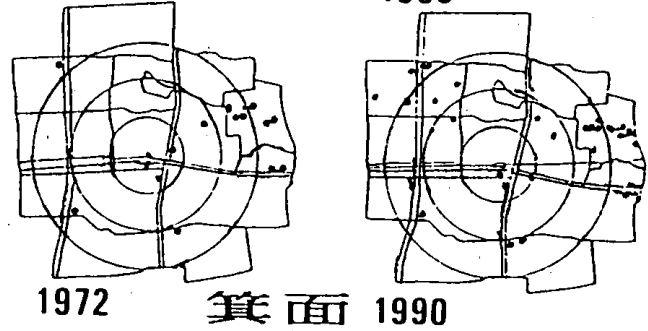

1972 留面 1990
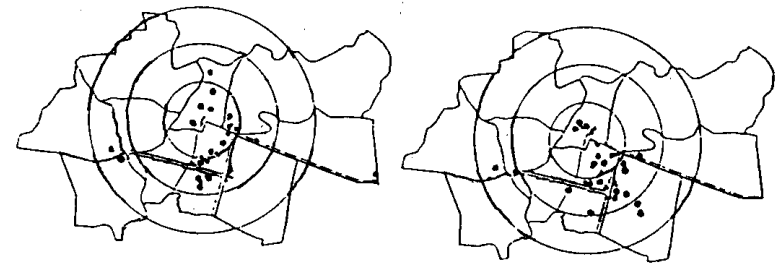

1984 住壳果 1990
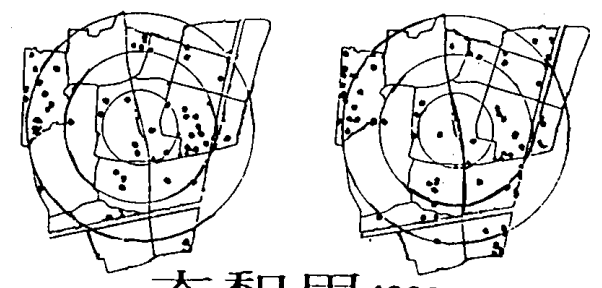

1984 大和田1990
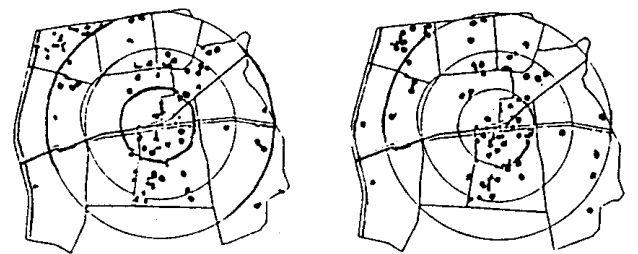

涟和 1990
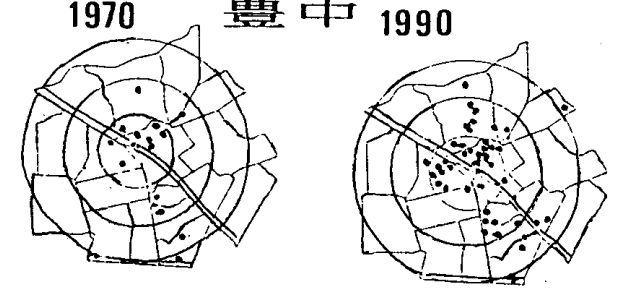

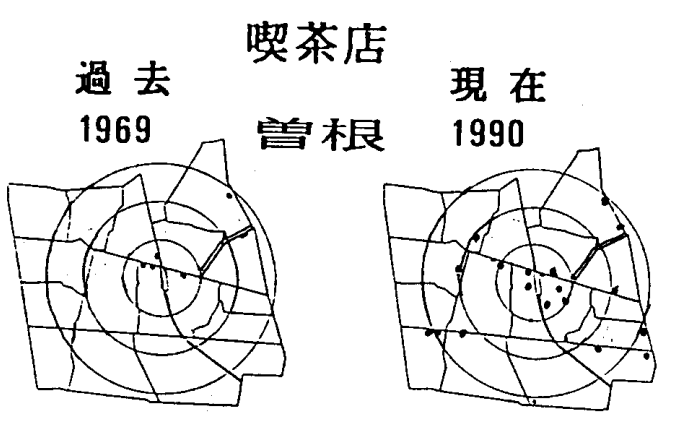

1984 閴

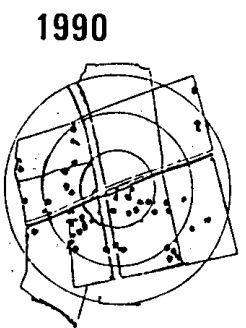

1977 新石切 1990
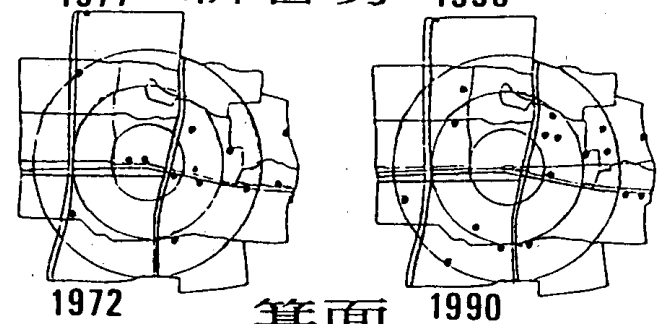

等面

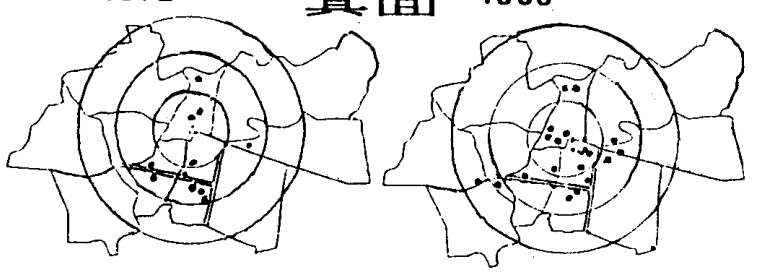

1984 住吉東 1990
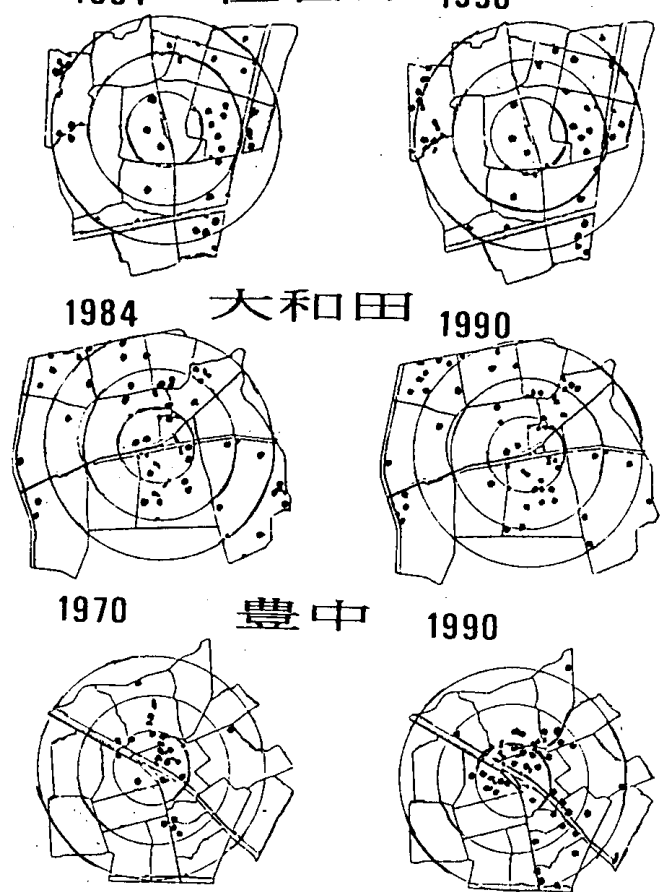

量中
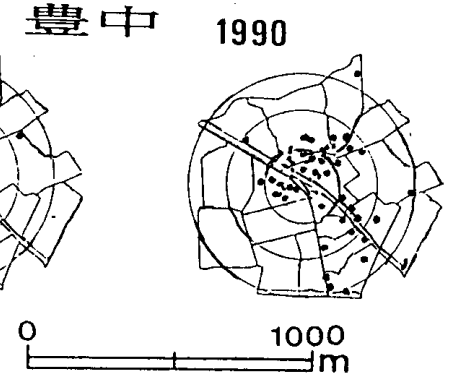

図ー3，各調查地域における各施設の分布実態（食堂・领食店と喍茶店） 
みられる。施設発生数と用途地域の関係をみると，近隣 商業地域, 商業地域, 第 2 種住居専用地域, 住居地域,

第 1 種住居専用地域の順に少なくなっている。

b ．曾根地域：商業地域は指定されておらず，駅を中心 にして東西方向の地域が近隣商業地域に指定され，施設 が集中して発生している。施設は西側の阪神高速道路大 阪池田線より東側の国道176号線の沿いに多く,東西の道 路をつなぐ道路沿いにす多く発生している。

施設発生数と用途地域の関係は, 面積が広い第 2 種住 居専用地域が最も多く，次いで商業地域，住居地域，第 1 種住居專用地域の順に少なくなっている。

c . 大和田地域：駅を囲んで商業地域，近隣商業地域に 指定されており，この地域に施設が多く発生している。 駅の東側と西側の工業，準工業地域を除くと，施設は全 範囲にわたって分布している。他には大和田地域の中央 部を南北方向に走っている道沿いにも施設が多く立地し ている傾向がみられた。施設発生数と用途地域の関係を みると, その面積が広い第 2 種住居専用地域, 商業地域, 近隣商業地域, 住居地域, 工業, 準工業地域の順に少な くなっている。

d. 豊中地域：駅に近いほど地域施設が集積する程度は 高くなっている。特に鉄道駅から半径0〜 $400 \mathrm{~m}$ 以内の距 離圈に施設の集中がみられた。その他にも，施設が幹線 道路沿いに発生する傾向がみられる。

施設発生数と用途地域の関係をみると, 商業地域, 近 隣商業地域, 第 2 種住居専用地域, 第 1 種住居専用地域, 住居地域の順に少なくなっている。

e . 新石切地域: 新石切駅は1986年にできた新しい駅で ある。この駅の設置前は当地域の中央部を南北に走って いる国道170号線の東側に施設が偏在していたが、駅がで きて 4 年経過した〈現在〉では西側にも施設数が増え，

〈過去〉より施設が駅周辺に全般的に分布する傾向がみ られる。

当地域の東西を通っている近鉄東大阪線沿いを駅から

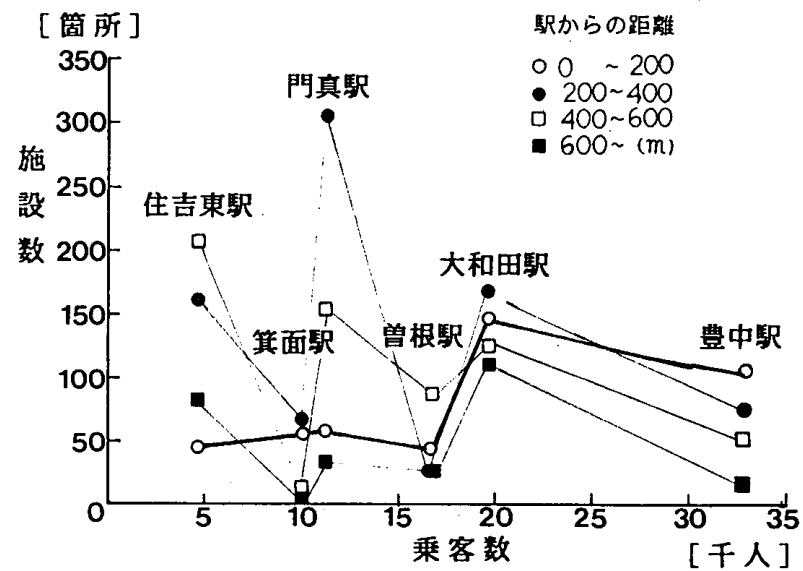

図ー4 施設数と乗客数の関係（過去）
西側にかけて商業地域に指定されている。施設発生数と 用途地域の関係をみると，住居地域，第 2 種住居専用地 域, 準工業地域, 近隣商業地域, 工業地域, 商業地域の 順に少なくなっている。他の調查地域では商業地域の施 設発生数が多いのに，新石切地域では商業地域に施設の 発生がみられないことが，特性としてあげられる。これ は，駅開設後の経過年数が少ないためと思われる。

f . 住吉東地域 : 施設の分布形態をみると, 〈過去〉と 〈現在〉いずれす全地域にわたって分布し，特に，駅か ら半径 $600 \mathrm{~m}$ 前後の離れた場所に施設の発生が目立ってい る。その他, バス便が通っている幹線道路沿いにも施設 が分布している。

住吉東地域は，駅の周囲が他地域とは違って，第 2 種 住居専用地域になっているが，比較的施設が多く立地し ている。また，駅を中心に西側の商業地域と，東側の住 居地域に施設の集中がみられるが、これらはとすに駅か ら $600 \mathrm{~m}$ 前後の距離である。

施設発生数と用途地域の関係をみると, 住居地域, 第 2 種住居専用地域，商業地域の順に少なくなっている。 住居地域に多くの施設が分布しているのはおべの筋など の主要道路が 2 本通っているためと思われる。

g. 門真地域：駅のすぐ北側が準工業地域であるため, 施設の発生は少ないが, 当地域を南北に走っている大阪 中央環状線および近畿自動車道の西側と，東西に走って いる大阪四日市線の南側は商業地域と近隣商業地域にな っているため，施設が多く発生している。施設発生数と 用途地域の関係をみると，近隣商業地域，商業地域，住 居地域, 第 2 種住居専用地域, 準工業地域の順に少なく なっている。

\section{4. 施設数と駅の乗客数との関係}

駅からの距離別にみた〈過去〉における施設数と駅の 乗客数の関係を図ー4 に，〈現在〉における萧客数と施

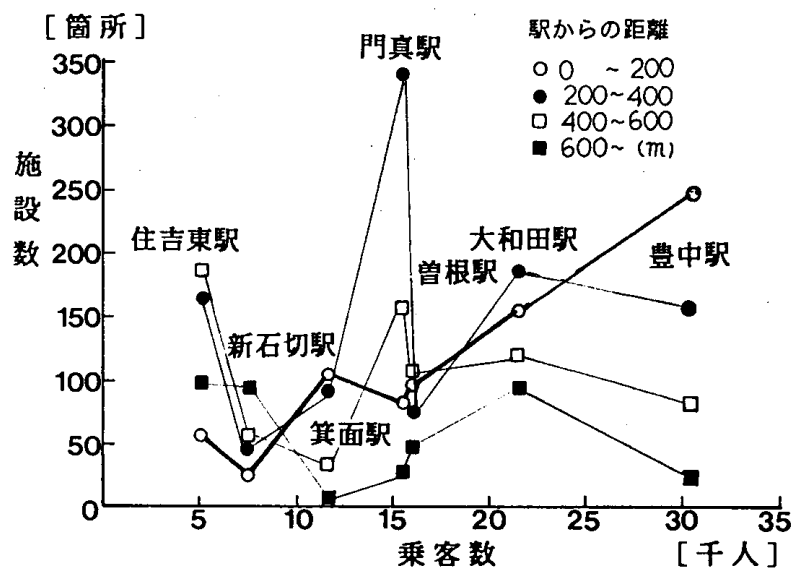

図-5 施設数と乗客数の関係（現在） 
設数の関係を図ー5に示す。

全体的にみると，駅を中心とする半径 $200 \mathrm{~m}$ 前後の圈域 においては，駅の規模が大きいはど施設数が多くなる傾 向がありこの傾向は〈過去〉ょりも〈現在〉のほうが 明確にみられる。しかし，駅から半径 $400 \mathrm{~m}$ より遠い距離 圈では乗客数と施設数の関係がみられない。これより， 今回調查した 1 日平均乗客数 3 万人程度までの鉄道駅が 地域施設の発生におよぼす範囲は，図一3の分布図からみ ると駅からおおむね半径200〜 400 $\mathrm{m}$ 以内であると考えら れる。

\section{5. 調査対象地域における施設原単位}

〈過去〉および〈現在〉の調查対象地域内における施 設原単位を業種別に示したものが図ー6である。この図 より明らかになったことは次のと㧍りである。

(1) 業種別の施設原単位

〈現在〉の施設原単位の值をみると、全調查地域の平 均値が 10 ヶ所 $/ 1$ 万人をこえるものは，食堂・飲食店 （36.2ヶ所）。契茶店（26.6ヶ所）。居酒屋・パブ（29.5 ヶ所），理・美容院（26.9ヶ所），洋服・衣料品店（20.3 ヶ所），パン・菓子店 (19.9ヶ所), 食料品店（11.0ヶ 所），クリーニング店（13.0ヶ所）である。

$5 \sim 10$ ヶ所 $/ 1$ 万人程度発生するすのとしては, 歯 科医院 $(6.6 r$ 所），寿司店（現在 7.2 所），内科・小 児科医院（6.7ヶ所），その他の医院（7.4ヶ所），酒店 (6.8ヶ所)，公共・行政施設 (7.8ヶ所)，寿司店（7.2 所)，学習塾（6.5ヶ所）である。

以上のように大部分の業種が人口 1 万人当たり 5 所 以上発生し, 平均值が 5 ヶ所／1万人末満のあのは, 食 肉・かしわ店（3.6ヶ所）などに限られている。

このように，駅が存在していない市街地における場合 （文3，文4）と比較して，同程度かやや高くなる傾向がみ られる施設は, 鉄道駅周辺地域に発生しゃすいことを示 唆している。

(2)施設原単位の経年変化

調查対象施設 16 業種における〈過去〉と〈現在〉の 施設原単位の 7 地域の平均值の変化をみる。

調查対象全地域で増加が顕著なるのとしては，学習塾 （過去 $1.5 \rightarrow$ 現在6.5ヶ所）, 居酒屋・パブ（過去16.0 現在 29.5 所），歯科矣院（過去 $4.1 \rightarrow$ 現在 6.6 所）， 洋服・衣料品店（過去12.7 $\rightarrow$ 現在 20.3 所），食堂・飲 食店（過去30.4 現在45.0ヶ所），クリーニング店（過 去9. $3 \rightarrow$ 現在 13 ヶ所）の 6 業種である。

施設原単位では食堂・飲食占が一番多いが, 増加割合 では 1.5 倍程度である。一方,学習塾は施設の原単位で は〈現在〉6.5ヶ所で, この中で一番低い值であるが, 倍数でみると 4.3 倍で，もっとも増加の割合が大きい。

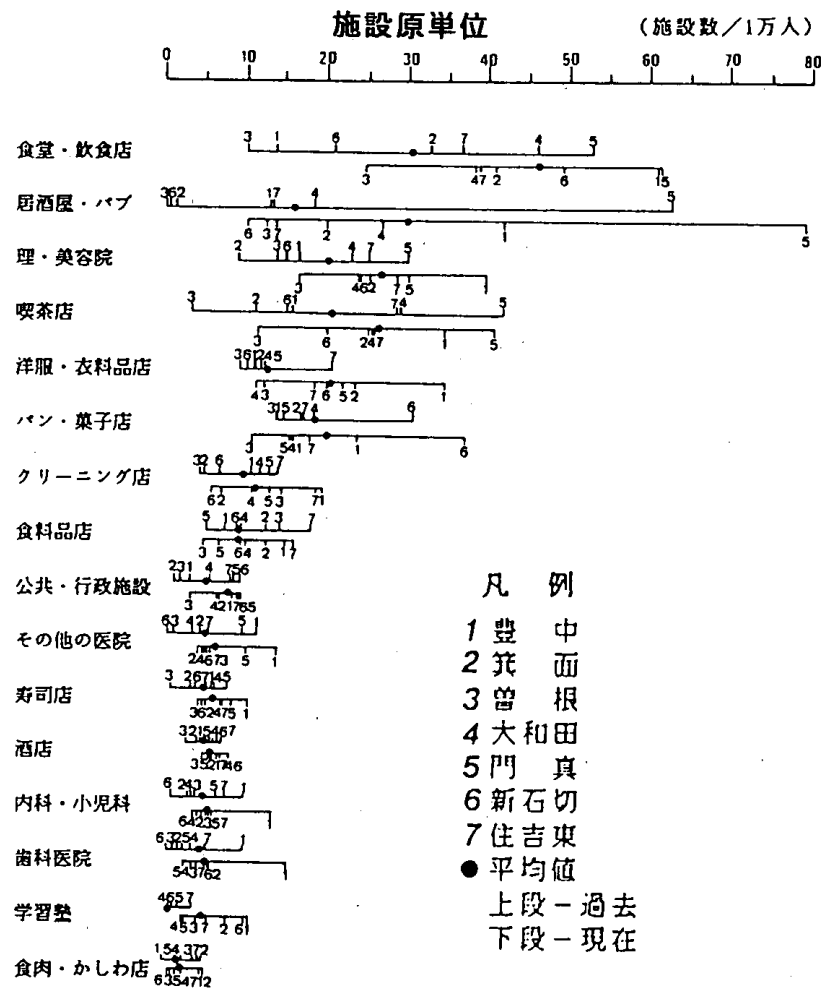

\section{図－6 過去と現在における各地域の 施設原単位の平均值}

やや增加したものとしては, 理 - 美容院 (過去20.5

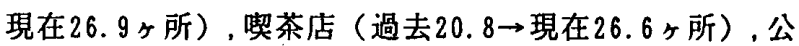

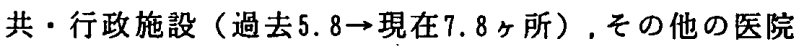
（過去5.6 $\rightarrow$ 現在 7.4 所），寿司店（過去5.4 $\rightarrow$ 現在 7.2 ヶ所），酒店（過去 $5.8 \rightarrow$ 現在6.8ヶ所），内科・小児科 医院（過去 $5.7 \rightarrow$ 現在 6.7 所），食肉・功わ（過去 3.1 $\rightarrow$ 現在 3.6 ヶ所）の 8 業種で, $1.2 \sim 1.3$ 倍程度の増加 である。

はとんど変化のない業種としては, パン・菓子店(過去 $18.1 \rightarrow$ 現在 19.9 ヶ所) と食料品店 (過去 $11.1 \rightarrow$ 現在 11.0 ヶ 所)の 2 業種である。施設原単位でみると, パン・菓子店 の場合はほぼ 20 ヶ所で多いが，増加割合でみると 1.1 倍弱であり，食料品店の場合は〈現在〉が〈過去〉ょり わずかであるが減少傾向にある。

\section{6. 駅からの距離と施設原単位の関係}

（1）駅からの距離別にみた施設原単位

施設原単位を業種別, 距離別にまとめたものの一部を 図一 7 に示す。

16 業種全体をみると豊中, 箕面, 曾根, 大和田地域 では，施設原単位の值が駅の近傍において高く，離れる にしたがって低くなる傾向が見られる。

一方, 門真地域では, 駅から半径200〜 400 m の距離圈 に施設が比較的多く発生し, 施設原単位の值が駅近傍の 

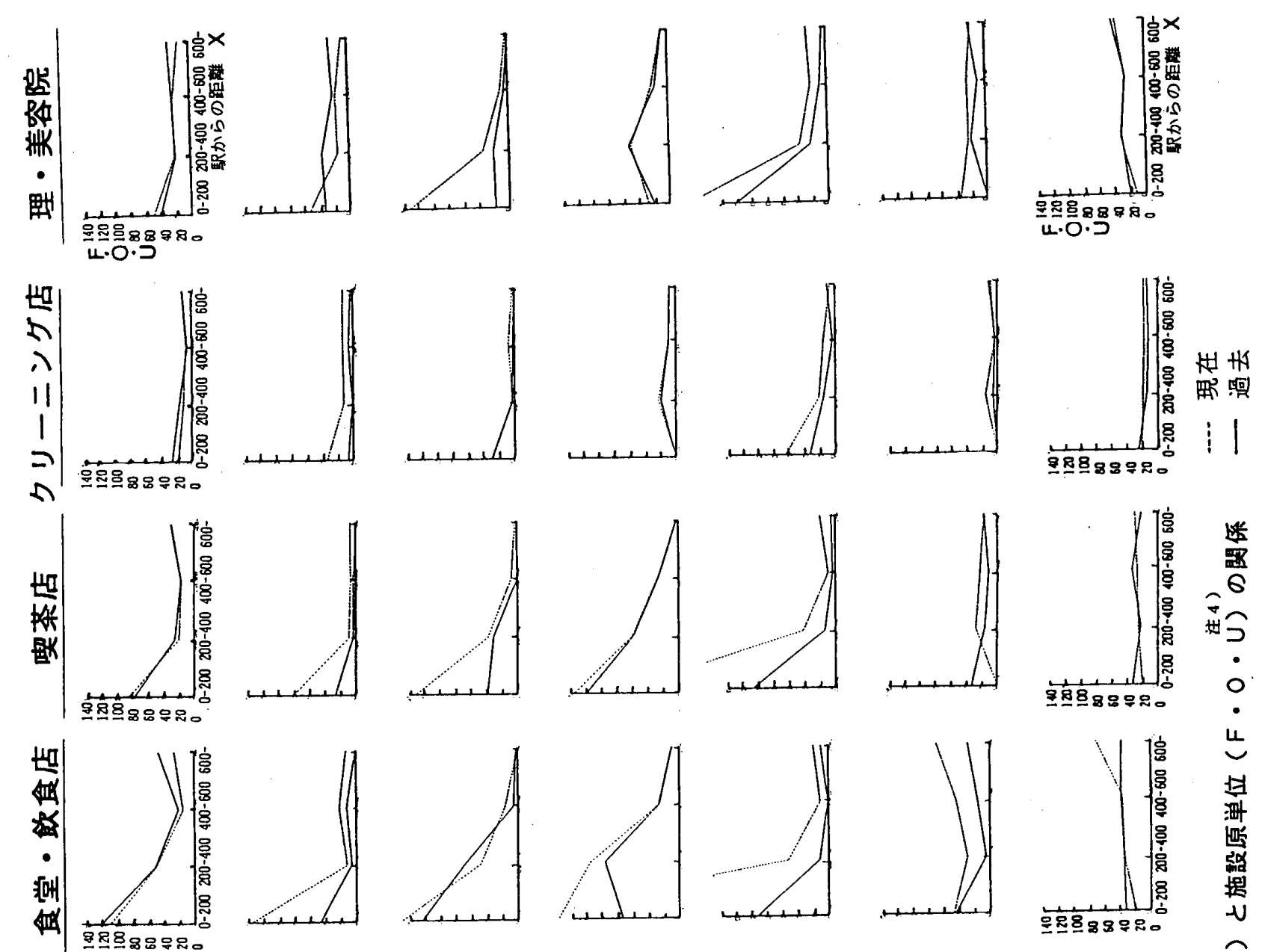

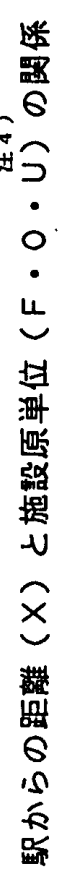
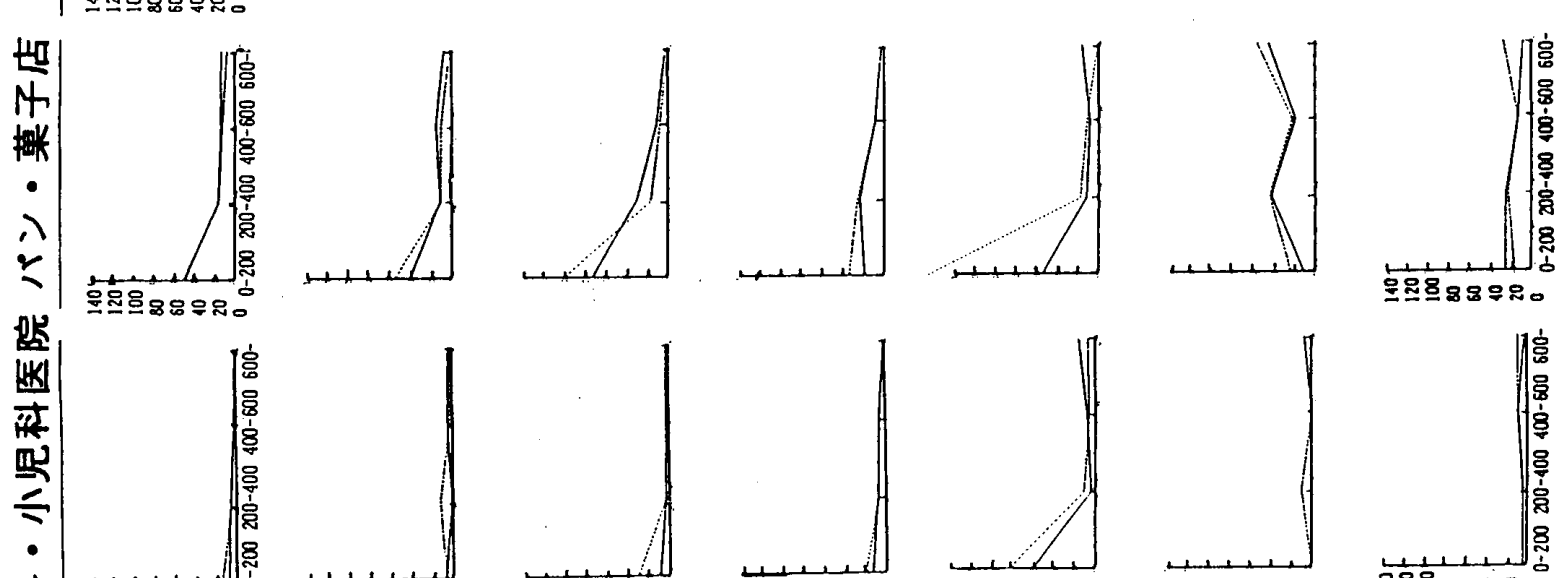

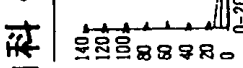
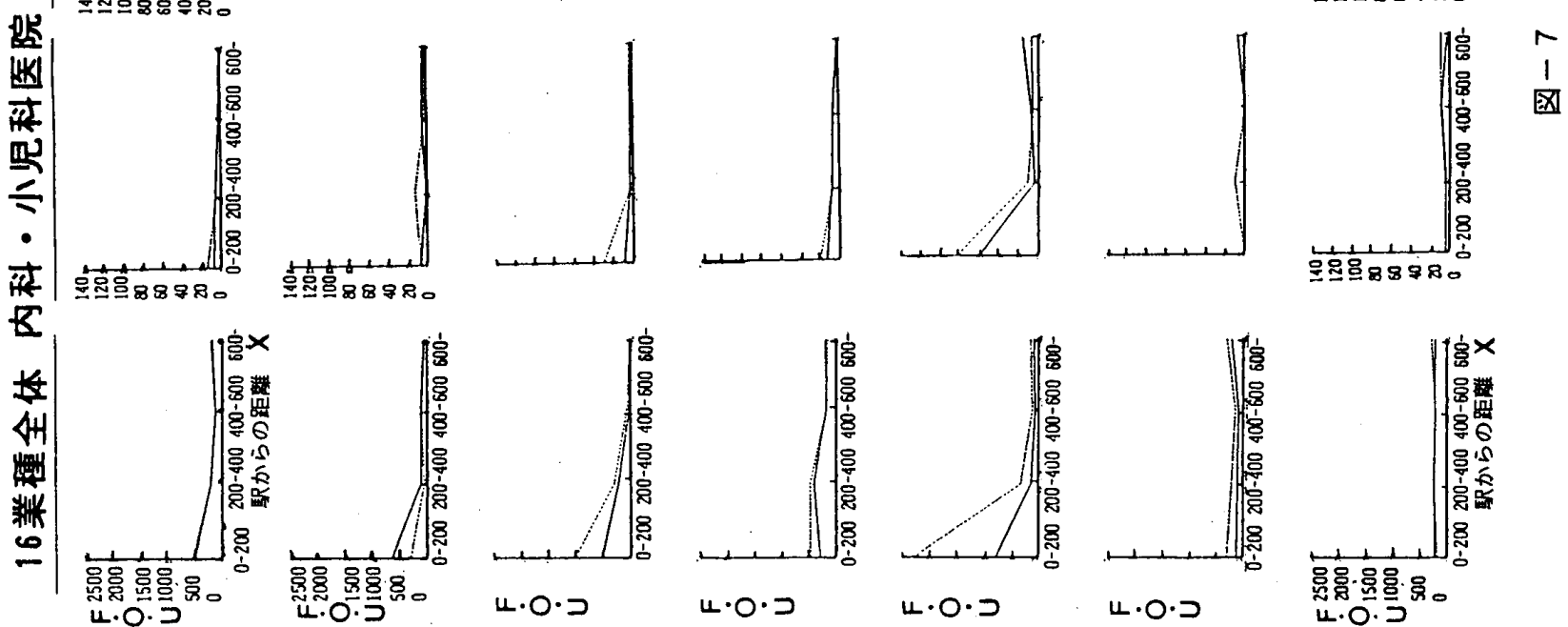

$4 \cdot 0 \cdot 5$

$4 \cdot 0 \cdot 3$
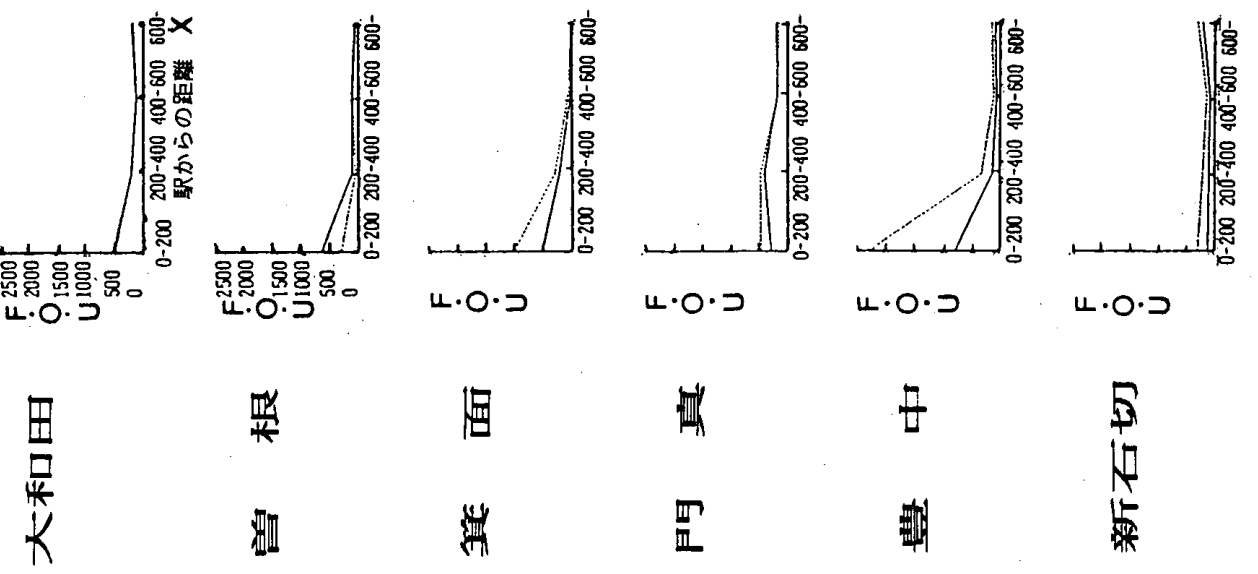

㧢

単

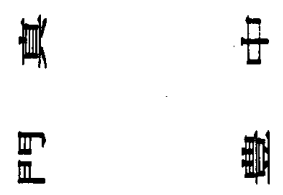

蛋

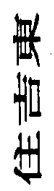


表ー2 駅からの距離別にみた施設原単位の変動パターンによる業種分類

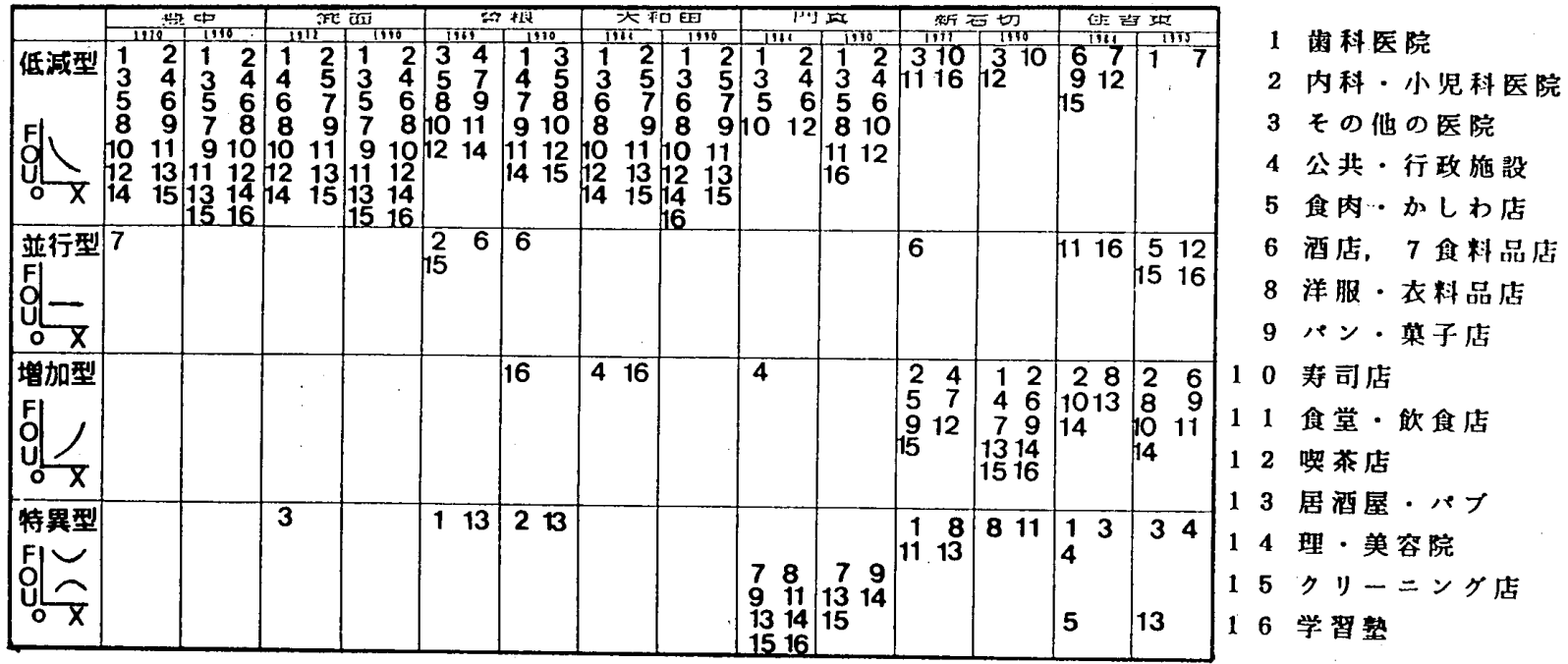

半径0〜 $200 \mathrm{~m}$ 圈以内の值より高くなっている。これは, 門真地域ではこの駅のすぐ西側に主要幹線道路である大 阪中央環状線と近畿自動車道路が通っていることや，駅 の南側に駅前広場が整備されたためと思われる。

住吉東地域です門真地域と同様，施設は駅から離れた ところに多く発生する傾向がみられる。これは，住吉東 駅周辺には 4 本の私鉄の 9 つの駅が住吉東駅からおよそ $600 \mathrm{~m}$ 前後のところに立地し，それらの駅周辺に発生して いる施設の影響を受けるためである。

新石切地域では, 駅周辺への施設集中の程度は他の調 查対象駅周辺ほど高くない。これは，新石切駅ができて 4 年しか経過していないので（1990年現在），駅の影響 がまだ十分に現れていないこと，駅の開設前から立地し ている幹線道路沿いの施設の影響が強いためと思われる。

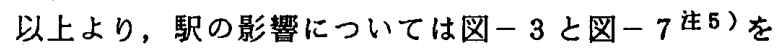
参考にしてみると，地域によって差はあるが，半径 200 〜 300mであることが読み取れる。

（2）施設原単位の変動パターン

駅からの距離と施設原単位の関係をグラフ化すると， そのパターンは「低減型」,「並行型」,「増加型」, 「特異型」の4つのタイプに分けられる。ここで「低減 型」は駅の近傍において高い施設原単位の值を示し，離 れるにしたがって低減するタイプ，「並行型」は駅から の距離に関係なくほぼ一定の値を示すタイプ，「増加型」 は駅から㺟れるにしたがって増加するタイプ、「特異型」 は駅から少し離れた所で高い（低い）值を示すタイプで ある。

駅からの距離と施設原単位の関係の変動パターンを業 種別に分類した結果を表ー 2 に示す。

「低減型」に属しているものは, 住吉東地域と新石切 地域を除く，他地域の大部分の施設である。

「並行型」、「增加型」に属しているものには, 内科・
小児科医院，酒店，公共・行政施設，クリーニング店, 学習塾といった，日常生活によく利用される施設が含ま れている。

「特異型」となるのは，駅から離れたところに国道な どの主要な幹線道路が通っている場合や, 駅周辺に公園, 工場や河川などがある場合に現れるタイプである。

新石切地域と住吉東地域では,多くの施設が「増加型」 に属しているが,これは前述したように，周辺の地理的 条件によるるのと考えられる。

一方, 門真地域では，施設の約半分が「特異型」に属 している。業種をみると, 食料品店, パン・菓子店, 洋 服・衣料品店, 理容・美容院, 食堂・飲食店などの施設 がこのタイプに属している。

新石切地域では, 歯科医院, 洋服・衣料品店, 食堂・ 飲食店, 居酒屋・パブといった業種がこのタイプにみら れた。住吉東地域では, 歯科医院, その他の医院, 公共・ 行政施設, 食肉・かしわ店, 居酒屋・パブなどが「特異 型」に属している。

以上のように，門真地域や住吉東地域のように地理的 与件によるすのや，新石切地域のようにまだ駅が開設さ れてますない例を除くと，大部分の施設が駅を中心とし た「低減型」を呈することがわかる。注6)

（３）施設原単位の変動パターンの経年変化

駅からの距離別にみた施設原単位の変動パターンの経 年変化を図 -8 に示す。この図より, 特に豊中地域, 箕 面地域, 曽根地域, 大和田地域においては, 大部分の施 設が「低減型」に属し，〈現在〉に近くなるはどその傾 向が顕著に現れていることがわかる。

豊中地域では, 変動パターンが「低減型」から変化し ていないものが 16 業種中 14 業種で,「並行型」から 「低減型」に変わった食料品店を含むと，15業種を占 めている。 


\begin{tabular}{|c|c|c|c|c|c|c|c|c|c|c|c|c|c|c|}
\hline & \multicolumn{2}{|c|}{ 贯 中 } & \multicolumn{2}{|c|}{ 篗 面 } & \multicolumn{2}{|c|}{ 暳 根 } & \multicolumn{2}{|c|}{ 大和日 } & \multicolumn{2}{|c|}{ P日 貝 } & \multicolumn{2}{|c|}{ 新石七刀 } & \multicolumn{2}{|c|}{ 住吉車 } \\
\hline & 1970 & 1990 & 1972 & 1990 & 1969 & 1990 & 1984 & 1990 & 1984 & 1990 & 1977 & 1990 & 1984 & 1990 \\
\hline 歯科医院 & 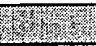 & 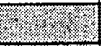 & 5 & 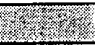 & & & & 37 & & & & & & \\
\hline 内科 - 小児科医 & 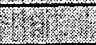 & (3) & 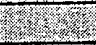 & (5t) & & & 2 & 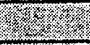 & $=2$ & & & & & \\
\hline その他の医院 & 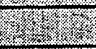 & & Xetren & $\sqrt{2 \sqrt{2}}$ & & Xis & $\sqrt{1.32}$ & S1730 & $\sqrt{14}$ & & & & & \\
\hline 公共 - 行政施設 & mint? & 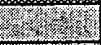 & 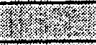 & 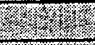 & $\sqrt[3]{2 \times 2}$ & & 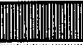 & 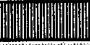 & $\sqrt{213}$ & & & & & \\
\hline 食肉・加し店 & 12. & 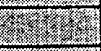 & $\sqrt{2}$ & 6. & X?/XY2 & & 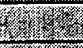 & $4 x^{2}$ & 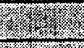 & & & & & \\
\hline 酒店 & 2. & 2. & m.7. & 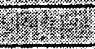 & & & $\sqrt{27}$ & 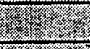 & & 4 & & & & \\
\hline 食料品店 & & 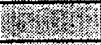 & Wringen & 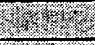 & & & 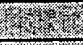 & 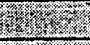 & & & & & & \\
\hline 洋服・衣料品店 & 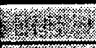 & $x^{2}+r^{2}$ & 6re? & \%? & $\sqrt{1.878}$ & 148 & 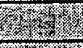 & 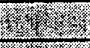 & & & & & 粗 & \\
\hline パン・菓子店 & trytre & 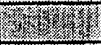 & triv? & (1) & 37tris & $\sqrt{179625}$ & (3) & Pry & & & & & 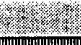 & \\
\hline 寿司店 & 6. & $3^{2}-126$ & (2) & 3ritrix & 178x/8 & rity & 71 & 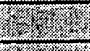 & 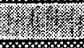 & ryes? & & & & \\
\hline 食堂·飲食店 & 26x & 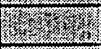 & ritive & 1. & $-\sqrt{1718}$ & e. & 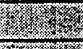 & 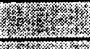 & & 27x & & & & \\
\hline 喫茶店 & Writy & Whing & 3. & $\sqrt{7}$ & 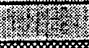 & 37xy & 25 & 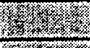 & 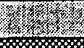 & 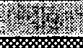 & & (2) & & \\
\hline 居酒屋・パフ & tringer & 2vinger & Trering & 2.1\% & & & 4 & WT: & & & & & & \\
\hline 理・美容院 & 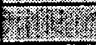 & 178m & mint? & 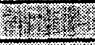 & 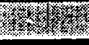 & Xry & 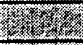 & 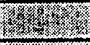 & & & & & & \\
\hline クリーニング店 & 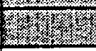 & trive & 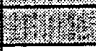 & $\sqrt{7}$ & & 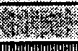 & 14t/4y & 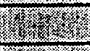 & & & & & & \\
\hline 学習整 & & 2017? & & min? & & & (In) & सा"W & & & 4 & & & \\
\hline
\end{tabular}

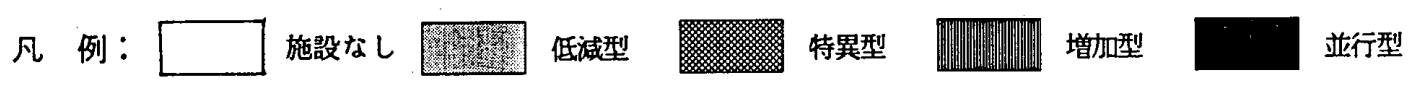

図一8 駅からの距離別にみた施設原単位の分布パターンの経年変化

箕面地域では，16 業種中 15 業種が「低減型」から 変化せず，「特異型」から「低減型」に変わったその他 の医院を含むと, 調查対象施設全体が「低減型」に属し ている。

曽根地域では，「低減型」から変化していないすのが 9 業種で,「特異型」から「低娍型」に変わった歯科医 院と，「並行型」から「低減型」に变わったクリーニン グ店を含むと 11 業種を占める。

大和田地域では，「低減型」から変化していないもの が 14 業種で,「増加型」から「低娍型」に変わった学 習塾を含むと 15 業種を占めている。

門真地域では, 「低減型」から変化していないものが 8 業種で,「特異型」から「低減型」に変わった食堂・ 飲食店，学習塾を含むと 10 業種を占めている。

新石切地域と住吉東地域では，他地域とは異なり「低 減型」から変化していないるのが全体の $1 \sim 2$ 割程度で あるが，これは駅周辺の環境条件が影響しているためと 考えられる。

以上のように, 多くの施設では変動パターンが「低隇 型」から変化していないことがわかる。さらに，〈過去〉 より〈現在〉の方が「低減型」に属する業種が多くなっ ており, 過去の調查時点に比べ現在に近づくほどその傾 向が強まっていることが明らかになった。

\section{7.まとめ}

1 日平均乗客数 30,000 人程度までの，鉄道駅周辺地域 における地域施設の分布実態の経年変化を調查分析した 結果，明らかになった主要な事項は次の通りである。 1) 施設原単位の值は，駅周辺でない他地域での調査結
果（文4）と比較して同一水準か, やや高い值を示し, 鉄道駅の存在が施設の発生に影響することがわかった。

2 ) 現在の駅からの距離別にみた施設原単位の変動パタ 一ンは,「低減型」,「並行型」，「増加型」，「特 異型」の4つのタイプに分類された。各業種がどの夕 イプに属するかは，駅の規模や周辺地域の人口，駅周 辺の用途地域などにより異なるが，駅が開設されて十 分な期間がすぎていて，かつ周辺地域に他の駅がない 場合は，大部分の業種が「低減型」に属することが明 らかになった。

3 ) 駅の乗客数と施設数の関係からみると, 1 日平均乗 客数 30,000 人程度の駅では，鉄道駅が地域施設の発生 に強く影響をおよぼす範囲は，駅から半径200〜 $300 \mathrm{~m}$ 程度の圈域であると推定される。

以上，鉄道駅周辺に立地する地域施設の分布実態の経 年変化を調查し，それらの分布とその経年変化について の法則性をある程度明らかにすることができた。しかし， 対象地域や駅の規模が限られており, 駅の影響圈等につ いて一般的な傾向を求めるには，さらに調查事例を增や す必要がある。

注

1) 1977 年の乗客数のデータがない新設の新石切駅を調查対象 に含めたのは，駅の開設が周辺の地域施設の発生状況によ゙ のように影罯するのかを開設前の実態から捉えるためであ る。

2）各地域ごとの過去の年次は以下のとおりである。

豊中1969年，箕面1972年，曽根1969年，大和田1984年，新 石切1977年, 住吉東1984年, 門真市1984年

3）（株）ゼンリンならびに吉田地図（株）発行の各調查時点 
における住宅地図を用いた。

4 )ここで，F・O・Uとは, Facilities' Original Unit （施設原単位）の略である。

5 ）図一7は，200m きざであるが，全施設を対象として100 $\mathrm{m}$ ごとにデー夕を採取した図ー9においても，新石切地域 と住吉東地域を除くと，施設原単位の值は駅から半径200〜 $300 \mathrm{~m}$ の圈域を越えると低下することがかかる。

(図一 9 参照)

6)これは，十分年月が経過し，駅の中心性が維持されたため と推测されるが, そのメカニズム等の詳細は現在分析中で ある。

\section{参考文献}

1) 李 明權, 柏原士郎, 吉村英咗, 横田隆司: 铁道駅周辺地 域における地域施設の分布実態とその経年変化に関する研

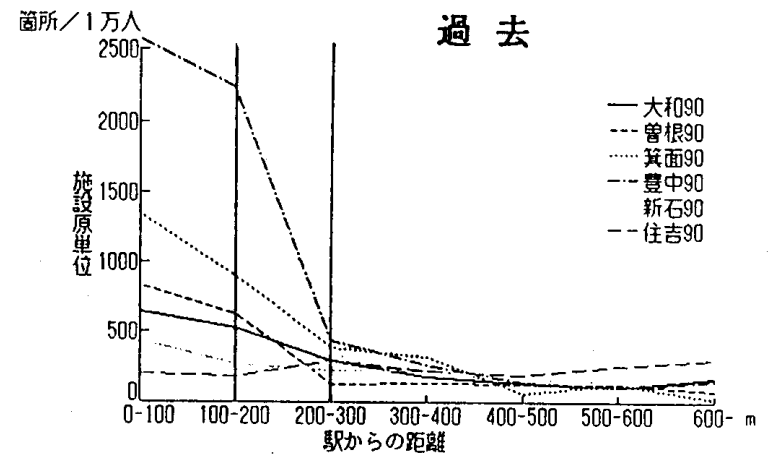

究, 第10回地域施設計画研究シンボジゥム論文果, pp. 153 ～158, 日本建築学会，1992年7月

2）横田隆司，柏原士郎，吉村英袏，洲脇規男：鉄道駅周辺地 域における地域施設発生の予测方法についてー混在型施設 の立地計画に関する研究一。第9回地域施設計画研究シンボ ジゥム論文果，pp. 91〜 96, 日本建筑学会, 1991年7月

3 ) S. Kashihara. H. Yoshimura and T. Yokota :A Comparative Study on Generation Process of Community Facilities in New Towns and Ordirary Built-up Areas. Trans. of A. I. J. , No. 377 , pp. 9 16,1987, 7

4）金漢洙，岡田光正，柏原士郎，吉村英祐，横田隆司：土 地区画整理により開発されたニュータゥンにおける地域施 設発生の予制方法についてーニュータゥンにおける地域施 設の供給計画に関する研究一，日本建築学会計画采論文報 告菓, 第407号.pp. 97〜105,1990年1月

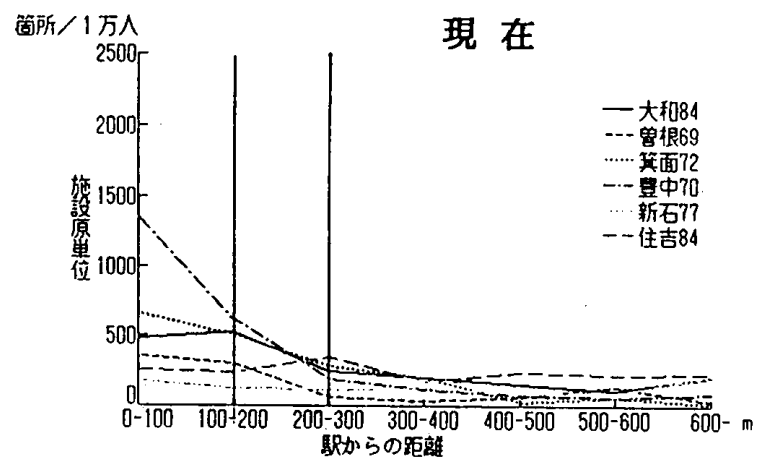

図ー9 駅からの距離と施設原単位の関係（距離を100 m 刻みにしたケース） 